\title{
In Vivo Characterization of Titanium Implants Coated with Synthetic Hydroxyapatite by Electrophoresis
}

\author{
Cristina COSTA de Almeida ${ }^{1}$ \\ Lídia Ágata SENA ${ }^{1}$ \\ MarceloPINTO ${ }^{2}$ \\ Carlos Alberto MULLER ${ }^{2}$ \\ José Henrique CAVALCANTI Lima ${ }^{3}$ \\ Glória de Almeida SOARES ${ }^{1}$ \\ ${ }^{1}$ Department of Metallurgical and Materials Engineering, COPPE/UFRJ, Rio de Janeiro, RJ, Brazil \\ ${ }^{2}$ Institute Oswaldo Cruz (FIOCRUZ), Rio de Janeiro, RJ, Brazil \\ ${ }^{3}$ Brazilian Institute of Implantology (IBI), Rio de Janeiro, RJ, Brazil
}

\begin{abstract}
This study compared in vivo the performances of commercially pure titanium (cp Ti) screw dental implants either uncoated or coated with synthetic hydroxyapatite (HA) by electrophoresis. The HA coating was characterized by scanning electron microscopy, energy dispersive spectroscopy (EDS) and Fourier-transform infrared (FT-IR) spectroscopy. Well-adhered carbonated-hydroxyapatite layers (4- to- $8-\mu \mathrm{m}$-thick) were obtained. In vivo tests were carried out by insertion of both uncoated and HA-coated implants into rabbit tibiae for 8 or 12 weeks. Histomorphometric analysis was performed by scanning electron microscopy with the aid of image-processing software. Results showed significantly greater bone-implant contact for HA-coated implants $(\mathrm{p}<0.05)$ than cp Ti implants. Comparison of bone content inside the screw implants showed no significant differences ( $p>0.05$ ) between both types of implants, although cp Ti had numerically higher percentage of bone content than HA-coated implants. In conclusion, the HA-coated implants had better performance regarding the bone-implant contact area than the uncoated implants; coating by electrophoresis proved to be a valuable process to coat metallic implants with an osteoconductive material such as hydroxyapatite.
\end{abstract}

Key Words: titanium, coating, hydroxyapatite, in vivo study.

\section{INTRODUCTION}

Due to its biocompatibility, titanium is considered the universal material for permanent implants, such as endosseous dental implants. In other applications requiring higher mechanical strength, titaniumbased alloys or Co-Cr alloys are preferred.

Coating metallic implants with biologically active materials, i.e., hydroxyapatite $\left(\mathrm{Ca}_{10}\left(\mathrm{PO}_{4}\right)_{6}(\mathrm{OH})_{2}\right.$; HA) aims to accelerate bone formation on the initial stages of osseointegration, thus improving implant fixation $(1,2)$. HA-coated dental implants are often recommended for the maxillary area where bone is less dense. HA coating is commercially produced by plasma spray techniques, which, in spite of the high productivity, demand expensive equipment and a robotic system to guarantee a uniform coating on complex shapes. In order to overcome plasma spray disadvantages, alternative processes have been developed (3-6).

Deposition by electrophoresis has some advantages over other techniques, including its short coating time (2-3 $\mathrm{min})$ and high reproducibility. However, hydroxyapatite adhesion to metallic substrates can be unsatisfactory without the previous blasting of titanium surface to enhance roughness, and calcination to improve coating adhesion (6-8). During heat treatment, hydroxyapatite, especially calcium-deficient-HA, can be partially converted into tricalcium phosphates $(\alpha-$ TCP or $\beta$-TCP), which are more soluble than the hydroxyapatite (9). Stability and solubility of calcium 
phosphate materials are strongly dependent on their composition and crystallographic structure. Among the tricalcium phosphates, amorphous calcium phosphate (ACP) is the most soluble, while sintered stoichiometric $\mathrm{HA}$ is the least soluble. Coatings with higher ACP/HA ratios will dissolve or biodegrade to a greater extent than coatings with a low ACP/HA ratio or higher cristallinity (9).

The purpose of this study was to compare the in vivo performances of titanium implants either uncoated or coated with synthetic hydroxyapatite by electrophoresis.

\section{MATERIAL AND METHODS}

Twenty screw-shaped commercially pure titanium (cp Ti) implants with an outer diameter of 3.75 $\mathrm{mm}$ and $7 \mathrm{~mm}$ in length were used in this study. Ten implants were left "as-received" (cp Ti implants) and ten were coated with synthetic hydroxyapatite by electrophoresis (HA-coated implants).

A precipitation-wet method was used to synthesize hydroxyapatite producing a powder with $1.66 \pm$ $0.04 \mathrm{Ca} / \mathrm{P}$ ratio. The morphology of HA powder showed acicular nanocrystals and cell parameters compatible with stoichiometric hydroxyapatite (6). The coating methodology was developed by Sena (6), following the Zhitomirsky and Gal-Or procedure (7). Titanium implants were used as cathode and platinum was used as anode in an electrophoretic cell with the electrodes positioned $40 \mathrm{~mm}$ apart. HA suspension in ethanol was prepared using hydrochloric acid as a dispersing agent, this process being carried out at $24 \mathrm{~V}$ for $3 \mathrm{~min}$. After deposition, the coated specimens were calcined in a tubular furnace at $800^{\circ} \mathrm{C}$ for $2 \mathrm{~h}$.

The characterization of the titanium implants was carried out on 4 specimens (2 HA-coated and 2 uncoated implants) by using a scanning electron microscope (DSM 940A model; Carl Zeiss, Jena, GmbH, Germany) on secondary electron and energy dispersive spectroscopy (EDS). A Nicolet-520G spectrometer with diffuse reflectance stage (Thermo Nicolet Corp., Madison, WI, USA) was used for Fourier-transform infrared (FT-IR) analysis.

Eight adult New Zealand rabbits of both sexes, weighing between 3.2 and $4 \mathrm{~kg}$, were used. Each animal received 2 implants, $1 \mathrm{cp}$ Ti (uncoated) and $1 \mathrm{HA}$ coated, both inserted in the tibial metaphysis. Four animals received cp Ti implants in the proximal tibial metaphysis and HA-coated implants in the distal tibial metaphysis. After a 4-week interval, the other four animals received the remaining implants following an inverse design, i.e., the HA-coated implants were inserted in the proximal tibial metaphysis while the $\mathrm{cp} \mathrm{Ti}$ implants were inserted in the distal tibial metaphysis. All implants were supposed to remain in place for 12 weeks.

The animals were fasted $12 \mathrm{~h}$ before surgery and no prophylactic medication was prescribed. Ketamine (Francotar, Virbac, Carros, French; $50 \mathrm{mg} / \mathrm{kg}$ body weight) and Acepromazine (Acepran, Univet, São Paulo, $\mathrm{SP}$, Brazil; $2 \mathrm{mg} / \mathrm{kg}$ body weight) were administered intramuscularly. After sedation, the left tibia of each animal was shaved and thereafter washed with Extran MA02 detergent (Merck, Rio de Janeiro, RJ, Brazil)

Surgical procedures were conducted in compliance with ethical principles for animal research, as approved by institutional guidelines. With the animals placed on their backs, a 3-cm-length incision was made through the skin and the fasciae in the tibial metaphysis to expose the tibial crest. Bone was perforated using segmental drills at low-speed with profuse saline cooling and the bone holes were carefully threaded. The implants were gently screwed into place and the fascia and skin were sutured with Prolene 2-0 Ethicon (Johnson-Johnson, São José dos Campos, SP, Brazil). The animals were allowed full weight bearing without any mobility restrictions immediately postoperatively.

Regrettably, two animals that received the implants at the second moment died before completion of the study, reducing the sample size to 6 animals and 12 implants (6 cp Ti and 6 HA-coated implants). To prevent further deaths, all animals were sacrificed at that time with intravenous overdoses of Tiopenthal (Cristália, Itapira, SP, Brazil): four completed approximately twelve postoperative weeks and the two survived up to eight weeks after surgery. Sections of each implant with surrounding bone tissue were removed and fixed with glutaraldehyde (Pelco International, Redding, CA, USA) in sodium cacodylate (Pelco International) at $\mathrm{pH}$ 7.2, dehydrated in graded acetone and embedded in low viscosity "Spurr" kit (Pelco International). Resin polymerization was carried out at $60^{\circ} \mathrm{C}$ for $24 \mathrm{~h}$. The 12 sections were bisected and each surface (A side and B side) was submitted to grinding with water-cooled 1200 grit $\mathrm{SiC}$ paper and sputter-coating with gold. Backscattered electron (BSE) images (X100 magnifi- 
cation) of both sides (A and B) of each section were obtained by SEM. The digital images were processed using image-analysis software (Global Lab Image, Data Translation, Marlboro, MA, USA). The percentage of direct bone contact was calculated as being the length of the implant in contact with bone divided by the total length of the screw (Fig. 1). In addition, the bone area inside the threads, expressed as a percentage of the total area, was also determined.

For statistical analysis, the variables were considered to have normal or about normal distribution. Bone-implant contact means for the three best consecu-

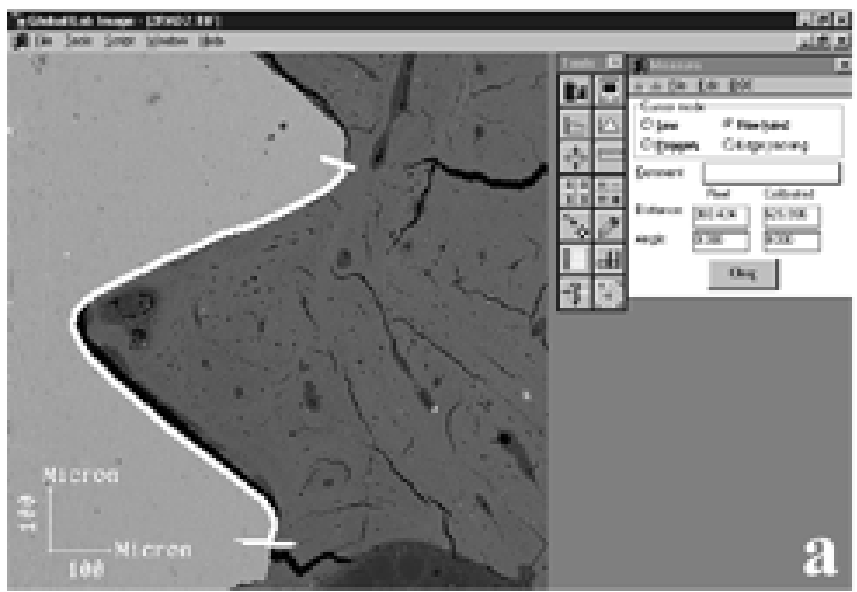

tive threads and for all threads, as well as the means of bone area inside the HA-coated and uncoated implant threads were compared using the $\mathrm{F}$ test $(\alpha=0.05 \%)$. Student's t-test for two samples supposing equivalent variances or different variances was also done.

\section{RESULTS}

\section{Coating Characterization}

SEM micrographs of HA-coated implants (Fig. 2) showed homogenous layers of hydroxyapatite with a

Figure 1. Calculation of the percentage of direct bone-implant contact - length of the implant in contact with bone (white line in b) divided by the total length of the screw (white line in a).
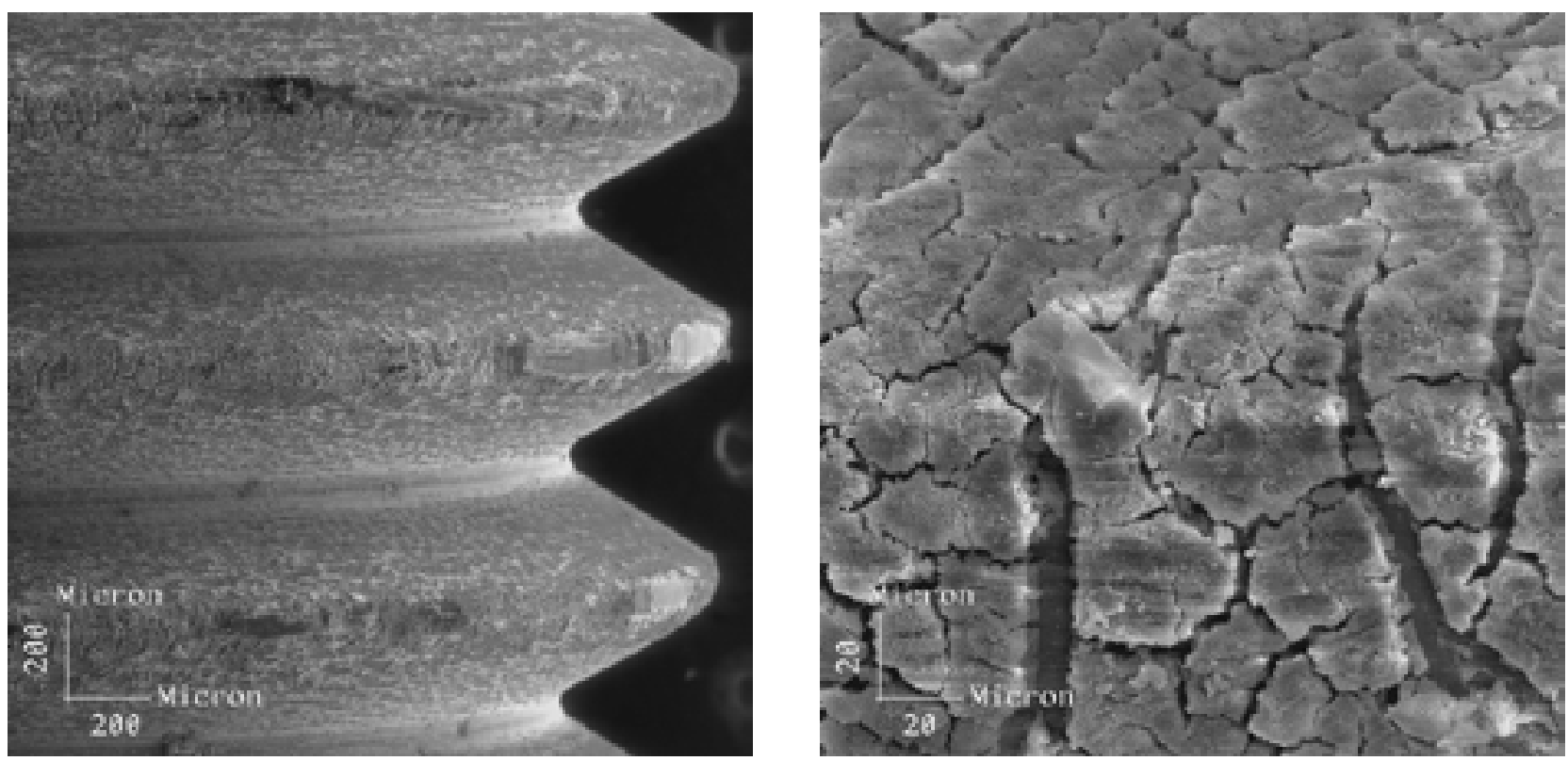

Figure 2. SEM micrograph of the HA-coated implant (original magnification X50) (left). "Crackled" appearance of the HA coating after calcination (original magnification X1000) (right). 
"crackled" appearance due to the volumetric contraction after calcination (Fig. 2). EDS spectra (Fig. 3) showed peaks of titanium, calcium and phosphorus. On FT-IR spectra (Fig. 3), the characteristic bands of the group $\mathrm{PO}_{4}{ }^{-3}\left(566,570,605,1030\right.$ and $\left.1100 \mathrm{~cm}^{-1}\right)$ of hydroxyapatite were identified. The band at $872 \mathrm{~cm}^{-1}$ correspondent to $\mathrm{CO}_{3}^{-2}$ in HA A sites and the bands at 1422 and $1449 \mathrm{~cm}^{-1}$ related to HA A and B sites were also identified, indicating that the coatings were composed by carbonated-hydroxyapatite.

\section{Histologic Analysis}

SEM images of bone sections showed an almost
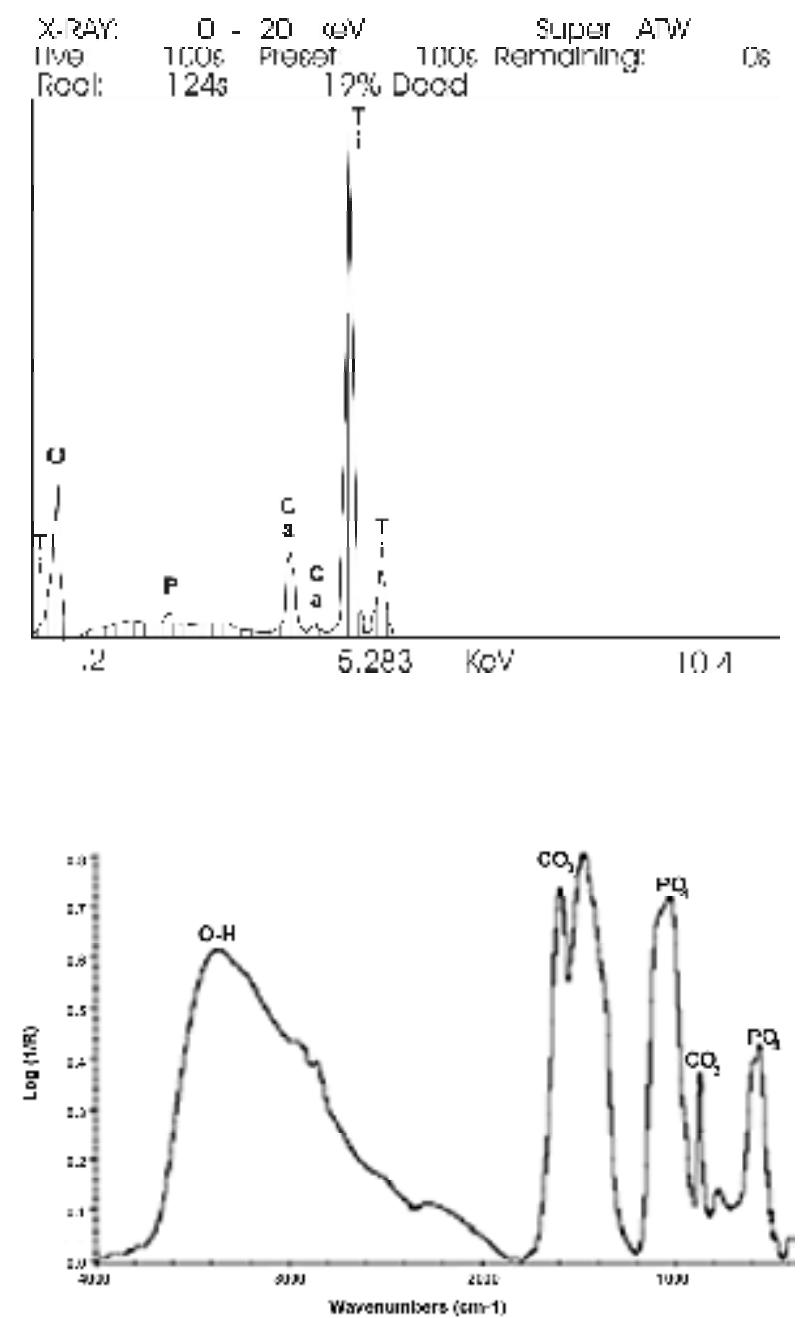

Figure 3. EDS spectrum of HA-coated implant showing peaks of titanium, calcium and phosphorus (top). FT-IR spectrum of the coating layer (bottom). continuous Ca-P-rich layer, with thickness ranging from 4 to $8 \mu \mathrm{m}$, well adhered to titanium implant (10). In Figure 4, a fracture line can be seen along the HAbone interface, probably caused by the rapid polymerization of acrylic resin. Regions where the fracture gap was thicker than $10 \mu \mathrm{m}$ were not considered as osseointegrated. For all HA-coated implants, this fracture occurred at the bone-hydroxyapatite interface, the coating layer remaining adhered to the metal.

\section{Histomorphometric Analysis}

Table 1 shows the means $( \pm \mathrm{SD})$ of the percentage of bone-implant contact obtained after 8 and 12

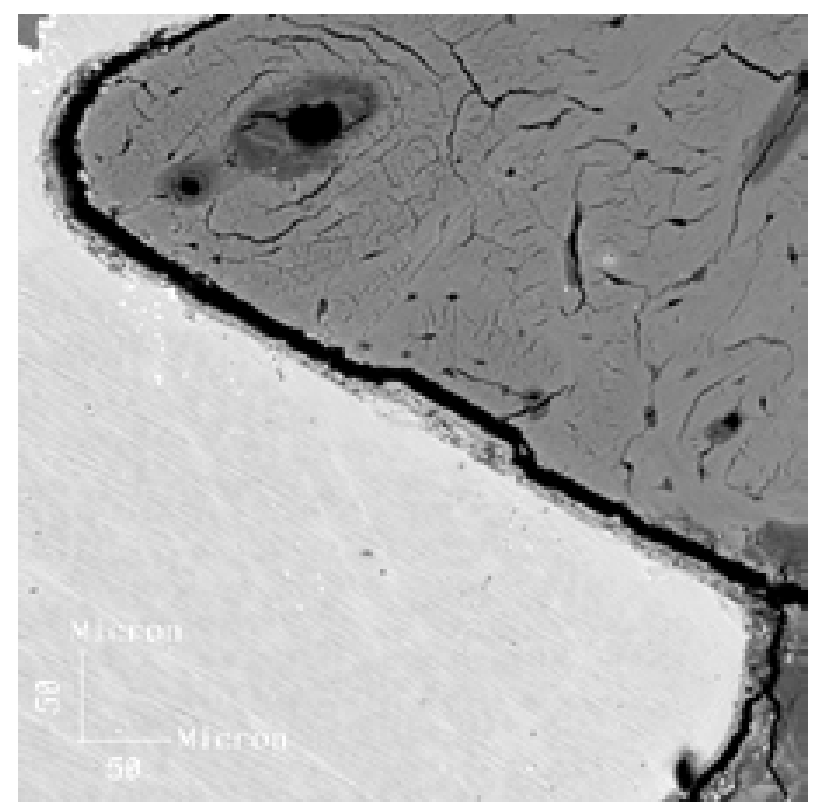

Figure 4. SEM micrograph showing a fracture line along the HAbone interface, probably caused by the rapid polymerization of acrylic resin (original magnification X1000).

Table 1. Bone-implant contact (\%) for cp Ti implants and HAcoated implants.

\begin{tabular}{lcc}
\hline & After 8 weeks & After 12 weeks \\
\hline All screw threads & & \\
$\quad$ Cp Ti & $43.82 \pm 0.95$ & $36.49 \pm 4.50$ \\
HA-coated & $63.20 \pm 10.60$ & $60.27 \pm 8.20$ \\
3 best consecutive & & \\
screw threads & & \\
Cp Ti & $59.47 \pm 3.81$ & $55.98 \pm 21.70$ \\
HA-coated & $80.10 \pm 5.87$ & $85.29 \pm 4.02$ \\
\hline
\end{tabular}


weeks for the three best consecutive threads and for all threads in the cortical area. No statistically significant differences $(p>0.05)$ were observed when the 8 - and 12 -week results were compared. Data were grouped, regardless of the osseointegration period, and the percentage of bone-implant contact of $\mathrm{cp}$ Ti and HAcoated implants was compared. Student's t-test showed significant differences $(\mathrm{p}<0.05)$ between uncoated and HA-coated implants for the three best consecutive threads and for all threads (Fig. 5). Means ( \pm SD) for the bone area inside the three best titanium threads and for all threads are given in Figure 6. Student's t-test showed no statistically significant difference $(p>0.05)$ between the results obtained for both types of surfaces.

\section{DISCUSSION}

In this study, titanium implants were satisfactorily coated with hydroxyapatite by using electrophoresis. According to Sena et al. (6) and Lacefield (11), calcination is of paramount importance to enhance adhesion and promote hydroxyapatite densification. HA deposition by electrophoresis was described by Ducheyne and Qiu (12) as the best technique to coat irregular surfaces, such as those of the screw-shaped dental implants. The "crackled" appearance of HA coatings (Fig. 2) is characteristic of metal-ceramic systems and is attributed to the development of thermal tensions due to the different expansion coefficients between the metal and ceramic layers during heating and cooling cycles $(6,8)$.

Carbonate bands in HA A and B sites were

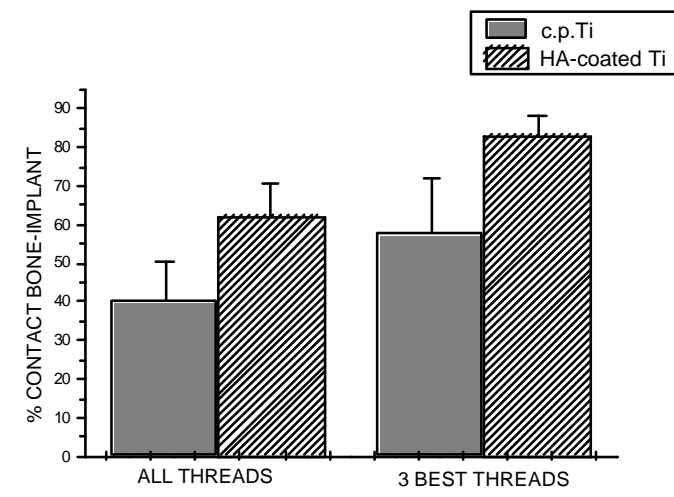

Figure 5. Percentage of bone-implant contact (means and SD) for the three best consecutive threads and for all threads of both HAcoated and uncoated implants. identified in the FTIR spectra (Fig. 3), suggesting that the HA coating actually is a carbonated-apatite coating. These results are justified by hydroxyapatite trend to incorporate carbonate ions from air, during synthesis and/or coating process. Although carbonate ions act to turn hydroxyapatite more soluble, this appears to be positive for the osseointegration process. The partial dissolution of hydroxyapatite makes the surrounding fluids rich in calcium and phosphate ions, which seems to induce the precipitation of "bone-like" apatite on implant surface (12-14). The release of calcium and phosphate ions followed by precipitation of "bone-like" apatite can trigger cellular differentiation and consequent bone formation (apatite plus osteoblast cells), and would perhaps explain why HA-coated implants tend to exhibit faster osseointegration than uncoated implants.

Several authors $(9,12,15)$ have stated that the role of coating ends after the initial stages of osseointegration. Therefore, the coating layer has not to be necessarily insoluble or thick, like plasma spray coatings usually are. Indeed, thick layers tend to exfoliate or delaminate (16) because the interfacial resistance decreases with increasing coating thickness. In a previous investigation, HA coatings deposited by plasma spray with thickness ranging from $75-150 \mu \mathrm{m}$ showed delamination, while 25 to 50 - $\mu$ m-thick coatings were found to have no effect on fatigue strength (17). By adjusting the process parameters, electrophoresis can produce coating as thin as $5 \mu \mathrm{m}$.

Gotfredsen et al. (18) and Vidigal et al. (19) have proposed the use of SEM images obtained with backscattered electrons for histomorphometric analysis. This methodology allows for use of thick sections and acquisition of high-contrast images because BSE contrast is highly dependent on atomic number of chemical specimens. Consequently, bone and calcium phosphate appears darker than titanium.

The non-significant differences observed after 2 or 3 months of osseointegration in this study are in agreement with the findings of other investigations $(18,20)$. The better performance of HA-coated implants regarding bone-implant contact percentage (Fig. 5) is also consistent with the results of previous reports $(2,18)$. However, the number of implants and animals used in this study cannot unequivocally support such comparisons.

Determination of the bone area inside the threads 


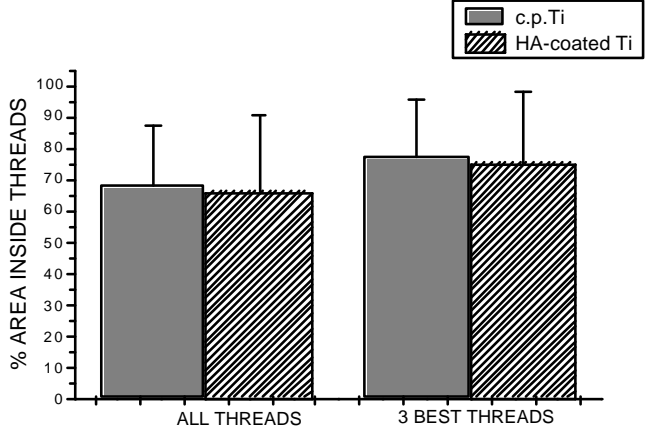

Figure 6. Percentage of bone area (means and SD) inside the titanium threads of both HA-coated and uncoated implants.

(Fig. 6) showed that the cp Ti implants presented slightly higher numerical values than the HA-coated implants, but this difference was not statistically significant. Likewise, Gottlander et al. (20) reported higher values for bone area inside titanium implant threads $(60.6 \%)$ than inside HA-coated implant threads (41.8\%) placed on tibia bone for 6 months. This behavior suggests that the efficacy of the coating layer is somehow restricted to the surroundings of the implant surface, without any long-distance effects.

The discrepancies between in vivo investigations and clinical applications must be appreciated andin vivo results cannot be directly extrapolated to the clinical reality. Moreover, the major limitation of our study was the small number of animals, which was further reduced with the loss of two animals during the experimental phase. The findings of this study led to the conclusion that the HA-coated implants had better performance regarding the bone-implant contact area than the uncoated implants. Coating by electrophoresis proved to be a valuable process to coat metallic implants with an osteoconductive material such as hydroxyapatite, for small or medium scale production. Further investigations should be carried out before this process can be rendered commercial.

\section{RESUMO}

Este estudo comparou in vivo a performance de implantes orais rosqueáveis fabricados em titânio comercialmente puro (Ti cp) e implantes recobertos com hidroxiapatita (HA) estequiométrica pelo processo de eletroforese. A camada recoberta foi caracterizada por microscopia eletrônica de varredura, espectroscopia de energia dispersiva e espectroscopia de infravermelho com transformada de Fourier. Foram obtidas camadas de carbonato-apatita bem aderidas ao substrato metálico, com espessura variando de 4 a 8 $\mu \mathrm{m}$. Testes in vivo foram realizados por meio da inserção de implantes em tíbias de coelho por períodos de 8 ou 12 semanas. A análise histomorfométrica foi realizada quantificando-se imagens obtidas em microscopia eletrônica de varredura e com o auxílio de um software de processamento de imagens. Os resultados mostraram que a porcentagem de contato direto ossoimplante foi significativamente maior para os implantes recobertos $(\mathrm{p}<0,05)$ do que para os implantes de titânio cp. A comparação da quantidade de osso no interior das roscas não mostrou diferença significativa para os dois tipos de implantes ( $p>0,05)$, embora os implantes de titânio cp tenham apresentado valores de porcentagem numericamente maiores que os implantes recobertos. Concluiu-se que os implantes recobertos com hidroxiapatita tiveram melhor performance em relação à área de contato ossoimplante que os implantes de titânio cp. O processo de eletroforese parece ser uma alternativa simples e viável para se recobrir implantes de titânio com material osteocondutivo, como a hidroxiapatita.

\section{ACKNOWLEDGEMENTS}

This research was supported by CNPq, CAPES, FAPERJ and FUJB. The authors are grateful to Neodent (Curitiba, PR, Brazil) for providing the titanium implants.

\section{REFERENCES}

1. Strnad Z, Strnad J, Povysil C, Urban K. Effect of plasma-sprayed hydroxyapatite coating on the osteoconductivity of commercially pure titanium implants. Int $\mathbf{J}$ Oral Maxillofac Implants 2000;15:483-490.

2. Vidigal GM Jr, Aragones LC, Campos Jr A, Groisman M. Histomorphometric analyses of hydroxyapatite-coated and uncoated titanium dental implants in rabbit cortical bone. Implant Dent 1999;8:295-302.

3. Kokubo T, Miyaji F, Min-Kim H, Nakamura T. Spontaneous formation of bone-like apatite layer on chemically treated titanium metal. J Amer Ceram Soc 1996;79:1127-1129.

4. De Groot K. Calcium phosphate coatings: alternatives to plasma spray. Proceedings of the 11th International Symposium on Ceramics in Medicine. Bioceramics 1998;11:41-43.

5. Prado da Silva MH, Lima JHC, Soares GA, Elias CN, De Andrade MC, Best SM, Gibson IR. Transformation of monetite to hydroxyapatite in bioactive coatings on titanium. Surface Coatings Technol 2001;137:270-276.

6. Sena LA, Andrade MC, Rossi AM, Soares GA. Hydroxyapatite deposition by electrophoresis on titanium sheets with different surface finishing. J Biomed Mater Res 2002;60:1-7.

7. Zhitomirsky I and Gal-Or L. Electrophoretic deposition of hydroxyapatite. J Mater Sci Mater Med 1997;8:213-219.

8. Wei M, Ruys A, Miltphorpe BK, Sorrel CC. Mechanical testing of electrophoretically deposited hydroxyapatite. Bioceramics 1999;12:463-466.

9. LeGeros RZ, LeGeros JP, Daculsi G, Kijkowska R. Calcium phosphate biomaterials: preparation, properties and biodegradation. In: Encyclopedic Handbook of Biomaterials and Bioengineering. Wise DL, Trantolo DJ, Altobelli DE, et al. (Editors). Part A: Materials. vol 2. New York: Marcel Dekker; 1995. p. 1429- 
1463.

10. Costa CA. Caracterização in vivo de implantes de titânio recobertos com hidroxiapatita estequiométrica por eletroforese. [Master's thesis]. Rio de Janeiro: COPPE, Universidade Federal do Rio de Janeiro; 2002. 112 p.

11. Lacefield WR. Current status of ceramic coatings for dental implants. Implant Dent 1998;7:315-320.

12. Ducheyne P, Qiu, Q. Bioactive Ceramics: The effect of surface reactivity on bone formation and bone cell function. Biomaterials 1999;20:2287-2303.

13. Kokubo T, Kim HM, Kawashita M, Nakamura T. What kinds of materials exhibit bone-bonding? In: Bone Engineering. Davies JE (Editor). Toronto: EM2 Corporation; 2000. p. 190-194.

14. Monteiro MM, Rocha NCC, Rossi AM, Soares GA. Dissolution properties of calcium phosphate granules with different compositions in simulated body fluid. J Biomed Mater Res 2003;1:299305.

15. De Groot K, Wolke JCK, Jansen JA. State of art: hydroxyapatite coatings for dental implants. J Oral Implantol 1992;20:232-
234.

16. Gross KA, Berndt CC, Iacono VJ. Variability of hydroxyapatite-coated dental implants. Int J Oral Maxillofac Implants 1998;13:601-610.

17. Lynn AK, DuQuesnay DL. Hydroxyapatite-coated Ti-6Al$4 \mathrm{~V}$. Part 1: the effect of coating thickness on mechanical fatigue behaviour. Biomaterials 2001;23:1-10.

18. Gotfredsen K, Wennerberg A, Johansson C, Skovgaard LT, Hjorting-Hansen E. Anchorage of TiO2-blasted, HA-coated and machined implants: an experimental study with rabbits. J Biomed Mater Res 1995;29:1223-1231.

19. Vidigal Jr GM, Sader MS, Soares GA. Osseointegration evaluation through histomorphometry on SEM images. Proceedings of the XVIII Meeting of the Brazilian Society for Microscopy and Microanalysis (SBMM), Águas de Lindóia, SP 2001;28-31.

20. Gottlander M, Johansson CB, Wennerberg A, Albrektsson T, Radin S, Ducheyne P. Bone tissue reactions to an electrophoretically applied calcium phosphate coating. Biomaterials 1997;18:551-557.

Accepted April 23, 2003 